\title{
ENSINO MÉDIO: FUNÇÃO DO ESTADO OU DA EMPRESA?
}

\author{
Dulce consuelo Andreatta Whitaker* \\ Elis C Ristina Fiam En GUE**
}

\begin{abstract}
RESU M 0: 0 presente artigo levanta questões importantes acerca da qualidade do ensino médio público quando comparado ao particular, a partir de dados da pesquisa " 10 anos depois: U nesp - D iferentes perfis de candidatos para diferentes cursos (Estudo de variáveis de capital cultural)", questionando a visão ideológica de que a escola particular coloca seus alunos mecanicamente nas melhores universidades. A presentando dados sobre a performance dos candidatos ao vestibular oriundos do sistema particular e do sistema público, o artigo mostra que, nos dois casos, a freqüência a cursinhos é uma constante, o que coloca em xeque a tão propalada maior qualidade do ensino médio particular.
\end{abstract}

Palavras-chave Ensino M édio; Ensino M édio Particular ePúblico; Efeito Cursinho; Acesso à U niversidade.

No momento em que o ensino médio é alvo de políticas governamentais, de preocupações nacionais e de avaliação, vale a pena relatar pesquisas que lançam luz sobre esse nível de ensino, para, no mínimo, abalar mitos veiculados pela mídia sobre as contradições entre escola pública e escola particular.

O s dados que vamos expor aqui, com suas análises e interpretações, foram extraídos da pesquisa "10 anos depois: Unesp - Diferentes perfis de candidatos para diferentes cursos (Estudo de variáveis de capital cultural)".

Esta pesquisa, que comparou vestibulandos e ingressantes do sistema Vunesp de 1985/1986 com os de 1995/1996, revelou inte-

* Professora do Programa de Pós-graduação em Sociologia e do Programa de Pós-graduação em Educação Escolar da FCL/ U nesp - Araraquara (SP).

* D outoranda no Programa de Pós-graduação em Sociologia da FCL/ U nesp - Araraquara (SP). E-mail: eliscf@uol.com.br 
ressante contraponto entre indicadores de capital cultural desses dois grupos de candidatos. N a avaliação de Prado (1999), representou uma "rara e feliz oportunidade de contrapor perfis de candidatos e ingressantes, com dez anos de intervalo, compreendendo as fases pré e pós-globalização".

Esse estudo tomou os dados dos vestibulares Vunesp de 1985 e 1986, investigou seis cursos representativos do conjunto daquela U niversidade e estabeleceu comparações verticais e horizontais com os dados de 1995/1996.

O s cursos escolhidos e tais comparações verticais e horizontais foram realizados como segue.

Tomaram-se, nos anos 80, o curso de maior e o de menor prestígio de cada uma das grandes áreas nas quais se divide o vestibular. 0 prestígio foi medido pela relação candidato/vaga: a maior relação candidato/vaga indicou o curso de maior prestígio da área, enquanto a menor relação candidato/vaga indicou o de menor prestígio - M edicina (Botucatu), Engenharia Elétrica (Ilha Solteira), Letras-Tradutor (S.J. Rio Preto): cursos de maior prestígio. Ciências Biológicas (S.J. Rio Preto), Engenharia C artográfica (Presidente Prudente), Ciências Sociais (M arília): cursos de menor prestígio.

Para os alvos deste artigo, vale destacar a descoberta da grande vinculação entre a Unesp e a escola pública, então chamada de segundo grau, da qual saía a maioria dos seus aprovados, mesmo para os cursos de maior prestígio, como M edicina, por exemplo. ${ }^{1}$

Decorridos dez anos, temos uma U nesp ampliada e intelectualmente enriquecida. Fomos obrigados então a acrescentar mais quatro cursos ao conjunto, para torná-lo mais representativo. Como resultado, além dos seis cursos analisados para 1985/86, temos agora mais duas Engenharias Elétricas (a de Guaratinguetá, criada em 1987, e a de Bauru, encampada em 1989) e mais dois cursos de prestígio na área de H umanidades: Arquitetura e D ireito (o primeiro do campus de Bauru, encampado em 1989, e o segundo do campus de Franca).

Além deste acréscimo de quatro cursos, temos o de Direito com dois turnos (o matutino e o noturno) e os dados de Ciências Sociais também desagregados para dois turnos, o que não nos foi oferecido dez anos atrás. Resultado: um conjunto que se estruturava em seis cursos para 1985/86, encontra-se hoje praticamente dobrado. As tabelas apresentam hoje dados para análise de doze cursos (são dez cursos, dois deles desdobrados em dois turnos). 
Estamos considerando como comparações verticais aquelas que se fazem entre os dois diferentes momentos do vestibular - anos 80 e 90, e como horizontais aquelas que emergem entre os diferentes cursos, para um mesmo ano.

Cumpre lembrar ainda que as análises de dados quantitativos, quando realizadas do ponto de vista sociológico e com intensa vigilância epistemológica, oferecem possibilidades de infinitas relações. Cabe ao sociólogo escolher aquelas que melhor respondem às inquietações que impulsionam o seu trabalho.

A análise tenta responder a várias perguntas. Mudou o perfil do vestibulando da Unesp? 0 que está por trás dessas mudanças? Elitizouse a Universidade Pública? Q uais as influências do cenário internacional que afetam escolhas profissionais?

Para discutir todas essas questões é preciso tomar os resultados globais da pesquisa. Para um artigo que lance luz sobre a questão do ensino médio escolhemos, no entanto, trechos da pesquisa que procuram responder a duas questões fundamentais:

- Anos 90: as camadas médias completaram sua fuga da escola pública de ensino médio?

" 0 "efeito cursinho": onde está a eficiência da escola particular de ensino médio?

\section{Anos 90: as camadas médias completaram sua fuga da escola pública

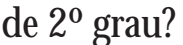

Um olhar comparativo entre as tabelas dos anos 80 e aquelas dos anos 90 revela queda substancial em alguns cursos das porcentagens de egressos da escola pública, então chamada de 20 grau, e o que é pior, uma mudança no movimento dos dados que parece indicar a total inadequação entre escola pública de ensino médio e Universidade.

Será que a escola pública de ensino médio tornou-se o espaço da pobreza? Vamos com calma. Há vários graus de pobreza. E pobre mesmo não chega ao ensino médio.

É preciso sempre refletir qualitativamente em cima dos dados. $\mathrm{E}$ com muita vigilância epistemológica, como dizem os críticos do positivismo.

$\mathrm{N}$ ão resta dúvida de que os dados referentes ao ensino médio freqüentado pelos vestibulandos de 1995/96 revelam ao olhar atento 
mudanças dramáticas nessa variável. Em 1985, apenas 47,9\% dos candidatos a M edicina vinham da escola particular de ensino médio. Era porcentagem significativa, mas não era maioria absoluta, conforme celebrado naquele momento. Porcentagem expressiva vinha da escola pública $(34,8 \%)$ e se somássemos a ela os outros casos de passagem pela escola pública, chegávamos a um percentual bastante alto de inscritos nas catego-

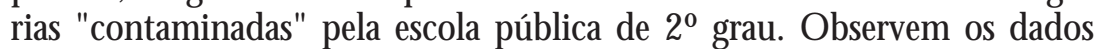
(Tabela 1). M ais de $50 \%$ dos candidatos a M edicina traziam a marca da escola pública. E o que consideramos fundamental em 1985. O s $34,8 \%$ dos egressos da escola pública de ensino médio serão 34,4\% dos matriculados. $\mathrm{N}$ aquele momento, a escola pública de ensino médio não parecia, portanto, atrapalhar a performance dos candidatos.

0 que parecia atrapalhar era "misturar" dois tipos de escola, já que a porcentagem dos aprovados egressos da escola particular cresceu para $54,4 \%$ à custa dessas outras categorias (ver dados na Tabela 1). ${ }^{2}$

Em 1995, no entanto, os dados para M edicina e seus resultados são melancólicos para a escola pública de ensino médio. Apenas 19,7\% dos inscritos vieram da escola pública, enquanto $67,9 \%$ vieram da particular. H á praticamente empate nas outras duas categorias. São apenas $11,6 \%$ contaminados pela escola pública. $\mathrm{E}$ nem dá para somá-los aos $19,7 \%$ egressos da escola pública, já que vão desaparecer no momento da matrícula. Passar pela escola pública de ensino médio é negativo para quem deseja fazer M edicina? O u os jovens que têm condições objetivas de aspirar ao curso de M edicina já não freqüentam a escola pública de ensino médio? Q uestão importante que discutiremos adiante.

Por ora, continuaremos a análise observando para M edicina a correlação entre esta variável e o sucesso/insucesso no vestibular, que pode nos levar a atribuir a ela um peso esmagador. Assim é que sobe para quase $90 \%$, na composição dos matriculados, a porcentagem dos egressos da escola particular de ensino médio (mais exatamente 88,9\%); enquanto cai para 7,8 a porcentagem dos formados pelo sistema público de ensino.

Basta um olhar rápido à Tabela 3 e veremos que os dados de 1996 confirmarão, com algumas nuanças, os resultados melancólicos de 1995. Embora crescendo, ligeiramente, o percentual de inscritos na categoria escola pública de ensino médio (todo na escola pública), no momento da matrícula a queda é ainda mais espetacular do que a do ano anterior. O s dados da categoria "todo particular" são semelhantes aos do ano anterior e assim o são os da "maior parte pública". Já a categoria "maior parte particular" tem modesto, porém inesperado sucesso $(5,7 \%$ dos inscritos serão $6,7 \%$ dos matriculados). 
Tabela 1

Distribuição doscandidatosinsaitosematriculados

segundo estudos do $2^{\circ}$ grau - Ano 1985

\begin{tabular}{|c|c|c|c|c|c|c|c|c|c|c|c|c|c|}
\hline \multirow[t]{2}{*}{ Área } & \multirow[t]{2}{*}{ Curso } & \multicolumn{2}{|c|}{ Todo pública } & \multicolumn{2}{|c|}{ Todo particular } & \multicolumn{2}{|c|}{$\begin{array}{l}\text { Maior parte } \\
\text { pública }\end{array}$} & \multicolumn{2}{|c|}{$\begin{array}{l}\text { M./parte } \\
\text { Particular }\end{array}$} & \multicolumn{2}{|c|}{ Suplet/Madur } & \multicolumn{2}{|c|}{ Não resp. } \\
\hline & & Inscr. & Matric. & Inscr. & Matric. & Inscr. & Matric. & Inscr. & Matric. & Inscr. & Matric. & Inscr. & Matric \\
\hline Biológicas & Méd & 34,8 & 34,4 & 47,9 & 54,4 & 8,6 & 5,6 & 7,0 & 4,4 & 0,7 & 1,1 & 1,0 & 0,0 \\
\hline Biológicas & Biol & 54,9 & 50,0 & 28,4 & 26,0 & 10,2 & 16,0 & 5,1 & 6,0 & 1,5 & 2,0 & 0,0 & 0,0 \\
\hline Exatas & E:Elét & 48,3 & 48,3 & 35,2 & 34,5 & 9,2 & 13,8 & 6,6 & 3,4 & 0,4 & 0,0 & 0,4 & 0,0 \\
\hline Exatas & E.Cart & 64,0 & 63,3 & 23,3 & 26,7 & 4,7 & 0,0 & 7,0 & 10,0 & 0,0 & 0,0 & 1,2 & 0,0 \\
\hline Humanas & Trad & 54,7 & 26,7 & 25,5 & 33,3 & 11,2 & 26,7 & 7,2 & 13,3 & 0,9 & 0,0 & 0,6 & 0,0 \\
\hline Humanas & C.Soc & 48,8 & 50,0 & 29,3 & 25,0 & 10,6 & 13,3 & 8,9 & 10,0 & 2,4 & 1,7 & 0,0 & 0,0 \\
\hline
\end{tabular}


Tabela 2

Distribuição doscandi datosinsaritosematriculados

segundo estudo do $2^{\circ}$ grau - Ano 1995

\begin{tabular}{|c|c|c|c|c|c|c|c|c|c|c|c|c|c|c|}
\hline \multirow[b]{2}{*}{ ÁREA } & \multirow[b]{2}{*}{ CURSO } & & \multicolumn{2}{|c|}{ Toda Pública } & \multicolumn{2}{|c|}{ Toda Particular } & \multicolumn{2}{|c|}{ Maior Parte Pública } & \multicolumn{2}{|c|}{$\begin{array}{l}\text { Maior Parte } \\
\text { Particular }\end{array}$} & \multicolumn{2}{|c|}{ Supletivo / Madureza } & \multicolumn{2}{|c|}{ Sem Resposta } \\
\hline & & & $\begin{array}{c}\% \% \\
\text { Inscrios } \\
\end{array}$ & $\%$ Matriculados & \begin{tabular}{|c|}
$\%$ \\
Inscritos \\
\end{tabular} & $\%$ Matriculados & \begin{tabular}{|c|}
$\%$ \\
Inscritos \\
\end{tabular} & $\%$ Matriculados & $\begin{array}{c}\% \\
\text { Inscritos } \\
\end{array}$ & $\%$ Matriculados & $\begin{array}{c}\% \\
\text { Inscritos } \\
\end{array}$ & $\%$ Matriculados & \begin{tabular}{|c|}
$\%$ \\
Inscritos
\end{tabular} & $\%$ Matriculados \\
\hline \multirow[t]{2}{*}{ Biologicas } & Medicina & Botucatu & 19,7 & 7,8 & 67,9 & 88,9 & 5,9 & 0,0 & \begin{tabular}{|c|}
5,7 \\
\end{tabular} & 2,2 & 0,3 & 0,0 & 0,4 & 1,1 \\
\hline & Biologia & Licenc. S. J. Rio Preto & 44,3 & 36,0 & 33,6 & 36,0 & 12,3 & 16,0 & 9,8 & 12,0 & 0,0 & 0,0 & 0,0 & 0,0 \\
\hline \multirow[t]{4}{*}{ Exatas } & Eng. Elétrica & Illha Solteira & 44,9 & 35,0 & 35,5 & 52,5 & 12,6 & 7,5 & 6,6 & 5,0 & 0,0 & 0,0 & 0,4 & 0,0 \\
\hline & Eng. Eletrica & Bauru & 35,0 & 16,7 & 52,7 & 66,7 & 6,5 & 5,0 & 5,2 & 10,0 & 0,2 & 1,7 & 0,5 & 0,0 \\
\hline & Eng. Elétrica & Guaratinguetá & 40,7 & 47,5 & 47,0 & 40,0 & 6,3 & 10,0 & 5,1 & 2,5 & 0,4 & 0,0 & 0,4 & 0,0 \\
\hline & Eng. Cartográfica & Pres. Prudente & 72,3 & 70,0 & 15,1 & 16,7 & 8,4 & 10,0 & 2,5 & 3,3 & 1,7 & 0,0 & 0,0 & 0,0 \\
\hline \multirow[t]{6}{*}{ Humanas } & Tradutores & Bacharelado & 41,0 & 18,8 & 37,9 & 59,4 & 12,3 & 18,8 & 8,4 & 3,1 & 0,0 & 0,0 & 0,4 & 0,0 \\
\hline & Direito & Matutino & 23,7 & 9,8 & 59,5 & 88,2 & 8,5 & 0,0 & 7,6 & 2,0 & 0,3 & 0,0 & 0,2 & 0,0 \\
\hline & Direito & Noturno & 50,8 & 43,1 & 31,0 & 43,1 & 9,6 & 9,8 & 6,7 & 3,9 & 1,1 & 0,0 & 0,9 & 0,0 \\
\hline & Arquitetura e Urbanismo & & 28,6 & 28,9 & 57,0 & 55,6 & 7,5 & 11,1 & 6,2 & 4,4 & 0,3 & 0,0 & 0,3 & 0,0 \\
\hline & Ciências Sociais & Matutino & 36,9 & 51,6 & 39,8 & 25,8 & 12,6 & 9,7 & 7,8 & 3,2 & 2,9 & 9,7 & 0,0 & 0,0 \\
\hline & Ciências Sociais & Noturno & 75,0 & 85,0 & 14,1 & 12,5 & 5,5 & 2,5 & 3,1 & 0,0 & 0,8 & 0,0 & 1,6 & 0,0 \\
\hline
\end{tabular}


Tabela 3

Distribuição doscandidatosinsaritosematriculados

segundo estudo do $2^{\circ}$ grau - Ano 1996

\begin{tabular}{|c|c|c|c|c|c|c|c|c|c|c|c|c|c|c|}
\hline \multirow[b]{2}{*}{ ÁREA } & \multirow[b]{2}{*}{ CURSO } & & \multicolumn{2}{|c|}{ Toda Pública } & \multicolumn{2}{|c|}{ Toda Particular } & \multicolumn{2}{|c|}{ Maior Parte Pública } & \multicolumn{2}{|c|}{$\begin{array}{l}\text { Maior Parte } \\
\text { Particular }\end{array}$} & \multicolumn{2}{|c|}{ Supletivo / Madureza } & \multicolumn{2}{|c|}{ Sem Resposta } \\
\hline & & & $\begin{array}{c}\% \% \\
\text { Inscritos }\end{array}$ & $\%$ Marticulados & $\begin{array}{c}\% \\
\text { Inscritos }\end{array}$ & $\%$ Matriculados & \begin{tabular}{|c|}
$\%$ \\
Inscritos
\end{tabular} & $\%$ Matriculados & $\begin{array}{c}\% \\
\text { Inscritos }\end{array}$ & $\%$ Matriculados & \begin{tabular}{|c|}
$\%$ \\
Inscritios
\end{tabular} & $\%$ Matriculados & \begin{tabular}{|c|}
$\%$ \\
Inscritos
\end{tabular} & \% Marriculados \\
\hline \multirow[t]{2}{*}{ Biológicas } & Medicina & Botucatu & 20,8 & 5,6 & 66,9 & 86,7 & 5,3 & 1,1 & 5,7 & 6,7 & 0,4 & 0,0 & 0,9 & 0,0 \\
\hline & Biologia & Licenc. S. J. Rio Preto & 65,3 & 28,0 & 23,1 & 48,0 & 5,0 & 12,0 & 5,4 & 12,0 & 0,4 & 0,0 & 0,8 & 0,0 \\
\hline \multirow[t]{4}{*}{ Exatas } & Eng. Elétrica & Ilha Solteira & 46,8 & 42,5 & 39,3 & 42,5 & 7,2 & 7,5 & 5,9 & 7,5 & 0,3 & 0,0 & 0,5 & 0,0 \\
\hline & Eng. Elétrica & Bauru & 37,9 & 28,8 & 50,4 & 61,0 & 6,3 & 6,8 & 4,1 & 3,4 & 0,3 & 0,0 & 0,9 & 0,0 \\
\hline & Eng. Elétrica & Guaratinguetá & 46,2 & 57,1 & 43,9 & 40,0 & 3,5 & 0,0 & 5,7 & 2,9 & 0,5 & 0,0 & 0,2 & 0,0 \\
\hline & Eng. Cartográfica & Pres. Prudente & 59,8 & 72,5 & 25,0 & 12,5 & 8,0 & 12,5 & 6,3 & 2,5 & 0,9 & 0,0 & 0,0 & 0,0 \\
\hline \multirow[t]{6}{*}{ Humanas } & Tradutores & Bacharelado & 47,0 & 34,4 & 35,4 & 50,0 & 8,8 & 9,4 & 7,3 & 6,3 & 0,5 & 0,0 & 1,0 & 0,0 \\
\hline & Direito & Matutino & 22,9 & 18,0 & 59,0 & 60,0 & 8,0 & 12,0 & 8,9 & 10,0 & 0,3 & 0,0 & 0,9 & 0,0 \\
\hline & Direito & Noturno & 49,4 & 28,0 & 32,1 & 50,0 & 8,6 & 6,0 & 7,8 & 14,0 & 1,3 & 2,0 & 0,9 & 0,0 \\
\hline & Arquitetura e Urbanismo & & 32,3 & 28,9 & 53,5 & 57,8 & 7,1 & 11,1 & 6,3 & 0,0 & 0,4 & 0,0 & 0,4 & 2,2 \\
\hline & Ciências Sociais & Matutino & 50,0 & 53,1 & 37,0 & 37,5 & 7,6 & 9,4 & 5,4 & 0,0 & 0,0 & 0,0 & 0,0 & 0,0 \\
\hline & Ciências Sociais & Noturno & 74,5 & 80,0 & 8,3 & 4,4 & 11,0 & 11,1 & 2,8 & 4,4 & 2,8 & 0,0 & 0,7 & 0,0 \\
\hline
\end{tabular}


O s dados vão confirmando o que já era visível a olho nu e proclamado por qualquer professor da escola pública. $\mathrm{N}$ ela só ficam aqueles que não podem pagar as caríssimas escolas particulares de ensino médio. ${ }^{3}$

$M$ ais do que melancólico, seria doloroso admitir desde já que a variável aqui tratada influi poderosamente nos resultados, o que não ocorria em 1985/86.

Para tanto, temos primeiro que observar o que acontece nos outros cursos. 0 curso de Biologia é ótimo para observação da variável acima, dado o fato de ser o de maior prestígio dentre os cursos de menos prestígio. Sua proximidade com a M edicina faz com que seja procurado por candidatos mais elitizados do que aqueles que buscam Ciências Sociais, por exemplo.

Vejamos primeiramente o que acontecia com este curso em 1985. N aquele momento, quase $55 \%$ dos candidatos vinham da escola pública de ensino médio. Essa porcentagem caía um pouco no momento da matrícula (50\%). M as, curiosamente, também caía para os egressos do sistema particular de ensino (de 28,4 para $26 \%$ ). Cresciam as categorias mistas e ficava patente que não havia, pelo menos naquele momento, nenhuma correlação entre essa variável e o sucesso/insucesso no vestibular.

Comemorava-se apenas o fato de que a categoria de crescimento fora a dos que fizeram a maior parte do ensino médio na escola pública (de 10,2 de inscritos para 16\% de matriculados), o que criava a seguinte observação - supremacia de egressos da escola pública na matrícula do curso de Biologia, já que $66 \%$ haviam passado por ela, "total ou parcialmente com predominância".

O s dados de 1986 apresentaram al gumas discrepâncias em relação a 1985, mas no conjunto revelaram o seguinte: "Em menor porcentagem que em 85 , mas ainda em maioria, $60 \%$ dos matriculados vieram, total ou parcialmente, de cursos de $2^{\circ}$ grau com predominância da escola pública." (W hitaker, 1989)

Era, portanto, ainda forte a correl ação entre escola pública e U niversidade pública nos anos 80 (evidentemente no caso U nesp).

Bem, parece que para Biologia as mudanças não são tão dramáticas. $44,3 \%$ dos inscritos ainda são egressos da escola pública de ensino médio, contra apenas $33,6 \%$ da particular. $\mathrm{N}$ as outras duas categorias temos $12,3 \%$ e $9,8 \%$, respectivamente maior parte pública e maior parte particular.

O s dados da matrícula vão mostrar que, embora a variável 20 grau tenha pesado consideravelmente, ela afetou negativamente apenas os que 
fizeram todo o ensino médio na escola pública. Vejam na Tabela 2 como subiram as porcentagens de todas as categorias que passaram pela escola particular de ensino médio. No entanto, o fato pode ser lido de outra forma, quando observamos que na composição do alunado do 1 - ano de Biologia em 1995, apenas 35\% vinham da escola particular de ensino médio. I gual porcentagem vinha da pública e o restante dos matriculados estava contaminado pelo ensino médio escola pública (Tabela 2).

$M$ as os dados de 1996 não nos permitem celebrar os "feitos" da escola pública. Eis que agora valentemente são $65,3 \%$ de inscritos apostando no menor prestígio do curso. M as caem espantosamente para $28 \%$ no momento da matrícula, enquanto crescem todas as outras categorias. E especialmente a categoria "todo particular" (Tabela 3).

Vejamos agora o que acontece com as Exatas. 44,9\% dos inscritos para Engenharia Elétrica de Ilha Solteira vieram da escola pública e $35,5 \%$ da escola particular de ensino médio. $12,6 \%$ fizeram a maior parte do ensino médio na escola pública contra $6,6 \%$ na particular.

É interessante já ir fazendo a comparação com os dados de 1985. Há muitos caminhos possíveis para analisar dados e comparar tabelas. Temos evitado o mecanicismo que toma os dados sempre da mesma forma, rigidamente, e buscamos abordagens variadas que deixam espaços para o contingente, aspecto de grande presença em todos os fenômenos humanos. ${ }^{4}$

N este momento, é importante lembrar que em 1985 o perfil dos candidatos da Unesp quanto ao ensino médio tinha a marca da escola pública. Em maior ou menor grau, mas sempre com mais de $50 \%$ os candidatos vinham da escola pública de ensino médio, total ou parcialmente. A Tabela 7 nos permite recordar esta predominância até mesmo entre os que passavam por diferentes tipos de ensino médio. Vejamos o que acontece hoje. Sem surpresas.

No curso de Engenharia Elétrica de Ilha Solteira, a variável influi sobre os resultados, embora não tão acentuadamente quanto em M edicina. Em relação àqueles que vieram da escola pública, 44,9\% caem para 35\% no momento da matrícula. Q uanto aos egressos da escola particular, sobem para 52,5\% (!!). Perderam todas as categorias contaminadas pela escola pública, conforme se pode observar pela Tabela 2.

O leitor pode observar na Tabela 1 que esta variável pouco influía sobre os resultados em 1985. Os dados de 1986, no entanto, já apontavam para a influência desta variável e perguntávamos naquela ocasião: "desvaneceu-se o caráter democrático do curso de Ilha Solteira? Teríamos 
de comparar estes dados com os dos anos subseqüentes para verificar qual dos 2 anos refletem melhor as tendências do curso." (W hitaker, 1989) $)^{5}$

O s dados de 1995/96 apontam na direção da confirmação do fenômeno detectado em 1986. M as em 1996 suavizam-se os "maus efeitos" da escola pública. Um olhar acurado à Tabela 3 revela variações menos dramáticas na transição inscritos/matriculados, embora negativas para a escola pública de ensino médio no vestibular para Engenharia Elétrica de Ilha Solteira.

Já em Bauru, a escolha no momento da inscrição privilegia a escola particular. Apenas 35\% vieram da escola toda pública contra $52,7 \%$ da particular. Porcentagens muito baixas vieram das categorias mistas (observem a Tabela 3 e vejam nos dados de 1996 como não mudou o perfil da procura em Bauru).

No momento da matrícula acentua-se a predominância dos egressos da escola particular, que passam a $66,7 \%$ contra apenas $16,7 \%$ da pública uma perda de quase metade dos pontos percentuais. Cai para $5 \%$ a já baixa porcentagem dos egressos da maior parte pública, enquanto quase dobra a da maior parte particular (os dados de 1996 são "animadores, já que a performance dos egressos da Escola Pública de ensino médio é menos desastrosa, caindo de $37,9 \%$ para $28,8 \%$ dos matriculados Tabela 3 - e fazendo diminuir o sucesso dos egressos da escola particular de 20 grau, que agora sobem menos).

M as a Engenharia Elétrica de Guaratinguetá parece ter clientela mais democrática. Embora a maioria dos inscritos venha da escola particular (47\% contra 40,7\% da pública), no momento da matrícula invertem-se essas porcentagens. Em Guaratinguetá não só há maior procura "pública" do que nas outras Engenharias Elétricas, como esta categoria apresenta maior sucesso na transição.

"Sucesso" também com os "parcialmente públicos", que sobem de $6,3 \%$ dos inscritos para $10 \%$ dos matriculados, enquanto a porcentagem com predominância da escola particular perde pontos - 5,1\% para 2,5\%.

Os dados de 1996 revelam queda percentual da inscrição dos egressos da Escola Particular (43,9\% de inscritos). E mais. A porcentagem cai para $40 \%$ no momento da matrícula (Tabela 3).

O s dados de G uaratinguetá nos aconsel ham prudência na avaliação do papel da escola pública de ensino médio. Engenharia Elétrica de G uaratinguetá é um curso de prestígio. No entanto, começa a apresentar aspectos democratizantes que se acentuam de 1995 para 1996. Discutiremos os fatores envolvidos mais adiante. 
Q uando chegamos ao curso de menor prestígio da área de Exatas, redobramos nossa prudência, já que Engenharia Cartográfica apresenta ainda mais intensa procura pelos candidatos da escola pública do que apresentava em 1985. São 72,3\% de inscritos que vieram da escola pública de ensino médio contra apenas $15,1 \%$ da particular. A mesma tendência verifica-se nas categorias mistas.

Em 1985 os candidatos da escola pública eram 64\%. É de se pensar que caiu ainda mais o prestígio do curso, já que perdeu candidatos da escola particular de ensino médio, justamente quando estes crescem substancialmente no conjunto (35,2\% dos inscritos em 1985 contra 15,1\% em 1995).

A variável ensino médio não tem em 1995 grandes influências nos resultados, para este curso sem prestígio.

D iremos resumidamente que as porcentagens apenas flutuam na transição, parecendo apontar tendências positivas para os egressos da escola pública.

Essas tendências são confirmadas pelos dados de 1996, quando $59,8 \%$ de inscritos com ensino médio na escola pública serão $72,5 \%$ dos matriculados. O bservem na Tabela 3 o fenômeno nas outras categorias: correlação negativa entre escola particular de ensino médio e matrícula, mas sem esquecer que este é o curso de menor prestígio da área.

O bservando-se a Tabela 1, podemos visualizar o que acontecia há 10 anos. Conforme já apontamos, $64 \%$ dos inscritos vinham da escola pública, contra $23,3 \%$ da particular. Interessante observar que àquela época era a escola particular que tinha correlação positiva com o sucesso na matrícula. O bservem os dados e principalmente a categoria "maior parte pública" que desaparece na transição. 0 s dados de inscrição de 1986 são muito semelhantes aos de 1985, mas no momento da matrícula al gumas nuanças já apontam para a maior correlação entre os matriculados deste curso e a escola pública de ensino médio.

Aqui cumpre introduzir o problema das segundas e terceiras listas, características dos cursos de menor prestígio e daqueles não-imediatamente profissionalizantes, o que nos leva a perguntar: os privilegiados da escola particular de ensino médio não foram aprovados ou não apareceram para efetuar suas matrículas?

A correlação entre U niversidade e ensino médio não pode ser pensada como avaliação deste último. D eve ser pensada sim como questão de classe social. 
Chegamos agora ao reino das H umanas. $\mathrm{O}$ curso de Letras (Tradutor e Intérprete) era, em 1985, o de maior prestígio na área. Vejamos 0 que mudou. Os candidatos egressos da escola pública são agora $41 \%$, enquanto $37,9 \%$ vieram do sistema particular. $12,3 \%$ são "parcialmente escola pública" contra 8,4\% "parcialmente da particular". 0 que chama a atenção nesta distribuição é que ela não é muito diferente daquela dada pelos candidatos de Ciências Biológicas. Já em 1985, notava-se esta relativa homogeneidade dos candidatos de São José do Rio Preto (Tabela 1). Embora a simetria seja hoje menor, não deixa de chamar a atenção 0 fato de que um curso de menor procura recebe inscrições com porcentagens de escolaridade de ensino médio muito semelhante ao de um curso de maior procura. 0 que poderia significar que os candidatos não avaliam tão diferentemente o prestígio dos dois cursos.

Um outro dado que chama atenção é o crescimento dos inscritos com $2^{\circ}$ grau particular, o que está coerente com as tendências já detectadas. Para tanto, basta um rápido olhar às três tabelas deste texto. $\mathrm{E}$ mais. Em 1985 a variável "escola pública de 2ํgrau" pesava negativamente nos resultados, o que não acontecia para os outros cursos, denunciando o caráter elitizado da desta carreira.

A Tabela 1 mostra uma queda vertiginosa na porcentagem dos que fizeram toda a escola de ensino médio pública $(54,7 \%$ para $26,7 \%$ ), com ganhos para as três categorias que passaram pela escola particular. Paradoxalmente, no entanto, o maior ganho estava na categoria "maior parte do 20 grau na Escola pública". 0 que sugere que a escola de ensino médio pública não tivera peso tão negativo nos resultados, sendo aquela queda vertiginosa algo contingente. O s dados de 1986 reforçavam esta nossa hipótese. 0 bservem:

Q uadro A

Efeito da variável Escola de 20 G rau.

Curso deTradutores deSão Josédo Rio Preto

Inscritos/matriculados 1986

\begin{tabular}{l|c|c|c|c}
\hline & Todo pública & Todo particular & Maior parte pública & Maior parte particular \\
Inscritos & 45,8 & 32,6 & 14,2 & 7,4 \\
Matriculados & 43,3 & 23,3 & 26,7 & 6,7 \\
\hline
\end{tabular}

0 que ocorre em 1995? Agora a queda é vertiginosa para os egressos da escola pública (de $41 \%$ para $18 \%$ ). Enquanto isso, aqueles que vieram 
da escola particular saltam de $37,9 \%$ para $59,4 \%$ - subida tão espetacular quanto o foi a queda da $1^{\underline{a}}$ categoria. $\mathrm{N}$ as outras duas categorias, no entanto, há nuanças difíceis de explicar: os que passaram a maior parte do ensino médio na escola pública fazem subir suas porcentagens, enquanto na última categoria (maior parte particular) essas porcentagens caem. Fenômeno que já acontecia em 1985/86, que apontamos como paradoxal e que aconteceria novamente em $1996 .{ }^{6}$

Passemos agora ao curso de Direito.

Como não poderia deixar de ser, os candidatos da escola pública de ensino médio têm menor porcentagem de procura no matutino $(23,7 \%)$ e maior no noturno $(50,8 \%)$, invertendo-se a relação quando tomamos aqueles que fizeram todo o ensino médio na escola particular (Tabela 2). 0 fenômeno se repete com os candidatos das categorias mistas, conforme os dados na mesma tabela: $8,5 \%$ contra 9,6\% e 7,6\% contra $6,7 \%$, respectivamente. A variável escola pública de 20 grau empurra as escol has para o noturno, embora não tão inexoravelmente. Afinal, 23,7\% mais $8,5 \%$ são mais de $30 \%$ de candidatos que passaram pela escola pública e ousam aspirar a um curso de prestígio no período diurno.

o importante é verificar se esta variável quando escola pública influi na aprovação. Influi sim e de forma esmagadoramente negativa sobre aqueles que ousam buscar cursos de prestígio indiscutível.

A influência negativa é tanto maior quanto maior seja o prestígio do curso, podendo não ocorrer, ou até ocorrer com sinal trocado (positivamente) se o curso tiver muito pouco prestígio. Assim é que, de 23,7\%, os candidatos da escola pública caem para $9,8 \%$ quando procuram o diurno para fazer $D$ ireito. A queda é menor quando procuram o noturno (de 50,8 para $43,1 \%$ ). Já os $59,5 \%$ da particular que buscam o diurno serão $88,2 \%$ dos matriculados. E os $31 \%$ que buscam o noturno serão $43,1 \%$ dos matriculados. N um efeito espetacular, os candidatos da escola particular ocupam a maioria esmagadora das vagas do diurno e fazem sentir sua presença marcante no noturno.

Sendo assim, no diurno quase desaparecem as outras duas categorias "contaminadas" pela escola pública (a de maior parte na escola pública desaparece mesmo - de 8,5 para 0\%). No noturno, essas categorias conseguem manter-se e os de maior parte do ensino médio na escola pública até crescem 0,2 pontos percentuais. $M$ as 0 impressionante efeito do ensino médio no curso de Direito, em 1995, será relativizado pelos dados de 1996, bastando para isso um olhar sociológico mais atento. Basta observar a Tabela 3 e verificar que os matriculados com ensino 
médio Escola Particular são agora $60 \%$ - uma queda de 28 pontos percentuais em relação ao ano anterior, com alterações em toda composição para a classe de 1음 ano matutino de 1996.

O s dados de Arquitetura e U rbanismo, embora apontando para uma predominância de candidatos da escola particular de ensino médio, vão mostrar que os seus efeitos sobre o sucesso no vestibular não são assim tão inexoráveis. O bservem na Tabela 2 que a maioria absoluta dos candidatos vem mesmo da escola particular de ensino médio. São $57,0 \%$ contra $28,6 \%$ da pública, com porcentagens pequenas nas outras categorias. $M$ as, na transição para a matrícula, os dados nos reservam surpresa. Esta variável, que tanta influência teve sobre o curso de D ireito e sobre Letras-Tradutores, de São José do Rio Preto, altera muito pouco os resultados para os futuros arquitetos de Bauru. $0 \mathrm{~s}$ dados apenas flutuam ligeiramente nas duas grandes categorias iniciais: $28,6 \%$ dos egressos da escola pública serão $28,9 \%$ dos matriculados. Já os 57,0\% da escola particular cairão apenas 1,4 pontos percentuais no momento da matrícula. Há uma paradoxal subida para os que fizeram maior parte do ensino médio na escola pública, caindo consequentemente a porcentagem da última categoria.

É preciso pensar as ambigüidades deste curso, que mistura ciência, arte e técnica, exige talentos específicos e se relaciona com mercado de trabalho abrangente e, portanto, sem definição exata, o que abre possibilidades de procura e aprovação contraditórias. Os dados de 1996, no entanto, comportam-se de forma menos democrática, restabelecendo 0 caráter elitizante do curso, sujeito a conjunturas.

- Muito bem! Chegamos ao curso de Ciências Sociais, no qual os dados costumam se "democratizar".

Com efeito, os egressos da escola pública aí comparecem na mais alta porcentagem (75\% de inscritos), evidentemente, para o período noturno. É menor a porcentagem dos que buscam o diurno (36,9\%).

O s egressos da escola particular até procuram esse curso. Afinal, 0 atual presidente da República e seu staff os inspiram. M as se concentram no diurno (39,8\%). A procura pelo noturno conta com apenas $14,1 \%$ egressos da escola particular. D a mesma forma, nas categorias mistas, é sempre maior a porcentagem que busca o matutino. Afinal, quem veio da escola pública já se concentrou na inscrição para o noturno.

D ifícil a comparação com 1985, já que na ocasião não tivemos os dados desagregados por período (noturno x diurno). Interessante observar que naquele momento $\mathrm{C}$ iências Sociais não apresentava porcentagem discrepante de inscritos da escola pública em relação ao conjunto, já que 
todos os cursos apresentavam estas porcentagens altas nessa variável. Alguns cursos de prestígio apresentavam índice maior neste item. Por exemplo, Letras-Tradutor apresentava $54,7 \%$ inscritos da escola pública, conforme Tabela 1.

O que mudou? Os outros cursos se elitizaram? 0 u as famílias daqueles mesmos estratos, como já sugerido, preocupam-se mais com 0 preparo dos filhos, apostando na escola particular de ensino médio? N esse caso, aquela clientela já apontada em 1985 como a mais desprivilegiada confirma suas escolhas por Ciências Sociais.

Vejamos agora se esta variável afeta a matrícula. Conforme sugerido, havendo menor prestígio do curso, no momento da matrícula crescem as porcentagens de egressos da escola pública de ensino médio, tanto no diurno como noturno.

Vejamos, contudo, o que aconteceu em cada caso.

O s egressos da escola pública eram $36,9 \%$ no diurno e se matricularam em $51,6 \%$ das vagas. No noturno cresceram de $75 \%$ para $85 \%$ confirmando o caráter "democrático" da clientela do noturno.

0 s remanescentes do ensino médio particular caem tanto no noturno como no diurno. São, porém, quedas diferenciadas. N o matutino eles caem 14 pontos percentuais, enquanto no noturno apenas 1,6 pontos percentuais. Qual o significado disso? U ma explicação possível é que os egressos da escola particular de ensino médio que escolhem o noturno estariam vindo de escolas técnicas e, sendo de famílias de menor poder aquisitivo, confirmam suas matrículas. Já aqueles que optaram pelo matutino cursaram escolas de prestígio no ensino médio, fizeram outros vestibulares e optaram por cursos de maior prestígio. ${ }^{7}$

O s dados das categorias parciais sugerem 0 acerto das considerações acima. Aqui precisamos chamar atenção para o curso supletivo, que comparece com 2,9\% dos candidatos inscritos para o matutino e que faz crescer para 9,7\% esta categoria no momento da matrícula (Tabela 2)

A presença de egressos do supletivo no curso de Ciências Sociais confirma 0 caráter "popular" desse curso, cujos aspectos democratizantes já chamavam a atenção em 1985/86 (ver Tabela 1). Essa presença se relaciona também com as possibilidades dadas pelos cursos de $\mathrm{H}$ umanas a alunos de mais idade, fenômeno esse visível a olho nu.

O s dados de 1996 apresentam nuanças difíceis de se analisar. No entanto, confirmam a predominância de candidatos da escola pública, tanto para o matutino quanto para o noturno (mais para o noturno obvia- 
mente). C onfirmam ainda a matrícula predominante de egressos da escola pública, apenas com inesperado aumento percentual no matutino e igualmente inesperada queda percentual no noturno. Tais quedas não alteram o perfil fundamental do aluno de Ciências Sociais de M arília, já detectado em 1985/86. No entanto, um dado nos chama a atenção. 0 egresso da escola particular do ensino médio (37\%) mantém a sua porcentagem no momento da matrícula $(37,5 \%)$ para o matutino, o que sugere estudantes de estratos mais elevados optando pelo curso de Ciências Sociais.

Em suma: de modo geral, os candidatos vêm do 20 grau particular para cursos de maior prestígio, o que não significa a não concorrência dos egressos da escola pública. Estes comparecem maciçamente para os cursos de menor prestígio. A novidade em relação a 85/86 é que esta variável está agora fortemente correlacionada com a matrícula - exceção para Ciências Sociais, Engenharia Cartográfica e Arquitetura, o que não nos autoriza a avaliar a eficiência do ensino médio, conforme já apontado.

Encerraremos este item, lembrando ainda que há 10 anos as camadas médias que compõem o grosso da procura pela universidade pública ainda mantinham seus filhos na escola pública de 10 e 2 graus. $N$ aquele momento, apontavam-se aspectos democráticos da clientela da U nesp. $\mathrm{N}$ ão foi ela que de lá para cá perdeu seus candidatos do 20 grau da escola pública. Foi a escola pública que perdeu os privilegiados que se destinam à Universidade. É necessário que se faça muita pesquisa para contrapor a fraqueza do 2 o grau da escola pública à opulência da escola particular de 2o grau, até porque as crianças das camadas médias afetadas pela política econômica neoliberal estão voltando para a escola pública, o que terá conseqüências a curto prazo.

II. 0 "efeito cursinho": onde está a eficiência da escola particular de ensino médio?

Pensar a influência do ensino médio isoladamente pode conduzir a conclusões precipitadas sobre relações que nunca são mecânicas. $N$ ada é produto de uma só variável. A compreensão do papel do cursinho na trajetória dos estudantes desvela outras relações que relativizam a eficiência ou não desses dois tipos de ensino médio no Brasil.

Ao analisar os dados de 1985, criou-se a expressão "efeito cursinho" para caracterizar o fato de que, embora a maioria dos candidatos prestasse o vestibular logo após o término do ensino médio, o sucesso era mais provável, em termos percentuais, para aqueles que 0 estivessem prestando 
um ou dois anos depois - fenômeno que ocorreu para quase todos os cursos (W hitaker, 1989). H oje, devemos ter cuidado com o uso dessa expressão, já que estão em andamento outras formas de preparo para 0 vestibular. Por exemplo: oficinas de redação, cursos de exatas com aulas individuais ou em pequenos grupos de alunos, aulas de línguas etc., que 0 jovem combina de acordo com as possibilidades financeiras da família.

Com efeito, observem os dados de 1985 na Tabela 4.

0 ano que apresentou a maioria dos candidatos a M edicina terminando o colegial foi 1984 , com $37,2 \%$. M as, no conjunto dos matriculados, foram apenas $16,7 \%$ - uma queda espetacular. Como complemento dessa queda, subiam as porcentagens para aqueles que haviam terminado o 2o grau há um, dois ou três anos - por hipótese, candidatos derrotados anteriormente e que estiveram em compasso de espera fazendo cursinho. Os dados de 1986 confirmaram essa tendência.

$\mathrm{H}$ istoricamente, nada aconteceu que pudesse alterar esse fenômeno, principalmente em se tratando de um curso de prestígio com procura cada vez mais intensa, como é o caso da M edicina de Botucatu (em vários anos, a maior relação candidato/vaga no país).

Assim é que, para o vestibular de 1995, o ano imediatamente anterior foi o que apresentou a maioria dos que terminaram o colegial e procuraram o curso de M edicina. São 43,9\%. M as esta porcentagem vai cair espetacularmente na transição. 0 mesmo tipo de deslocamento ocorrido em 1985/86. Observem a Tabela 5.

$\mathrm{N}$ a inscrição, a porcentagem é tanto menor quanto mais distante esteja a categoria do momento do vestibular. $\mathrm{N}$ a matrícula, a porcentagem maior se desloca para a categoria dos que terminaram o colegial em $1993(41,1 \%)$. Todas as outras categorias crescem, confirmando o "efeito cursinho".

Para o vestibular de 1996, o fenômeno se repete com poucas nuanças. 0 deslocamento é o mesmo observado para 1995: na inscrição, a maioria dos candidatos estava na categoria conclusão do 20 grau em 1995 (43,6\%). Já na matrícula, a maioria se desloca para a categoria 1994 com uma porcentagem ainda mais alta. A queda da porcentagem dos recém-formados no colegial é ainda mais espetacular do que já o fora em 1995. À custa dela, todas as categorias sobem com uma nuança de exceção em relação aos candidatos mais velhos, o que aliás já ocorrera em 1985/86, como se vê pela Tabela 6.

O s dados sugerem que em nada adiantou às famílias das camadas médias tirar seus filhos da escola pública. 
Tabela 4

Distribuição doscandidatosinsaritosematriaulados, conformeano detérmino do segundo grau, no Vestibular Unesp 1985

\begin{tabular}{|c|c|c|c|c|c|c|c|c|c|c|c|c|c|c|c|c|c|}
\hline \multirow[t]{2}{*}{ Área } & \multirow[t]{2}{*}{ Curso } & \multicolumn{2}{|c|}{1979 ou antes } & \multicolumn{2}{|c|}{1980} & \multicolumn{2}{|c|}{1981} & \multicolumn{2}{|c|}{1982} & \multicolumn{2}{|c|}{1983} & \multicolumn{2}{|c|}{1984} & \multicolumn{2}{|c|}{1985} & \multicolumn{2}{|c|}{$\begin{array}{l}1986 \text { ou após ou não } \\
\text { resp. }\end{array}$} \\
\hline & & Inscr. & Matric. & Inscr. & Matric. & Inscr. & Matric. & Inscr. & Matric. & Inscr. & Matric. & Inscr. & Matric. & Inscr. & Matric. & Inscr. & Matric. \\
\hline \multirow[t]{2}{*}{ Biológicas } & Med. & 4,3 & 2,2 & 3,3 & 1,1 & 7,0 & 10,0 & 15,7 & 31,1 & 29,9 & 38,9 & 37,2 & 16,7 & 1,5 & 0,0 & 1,1 & 0,0 \\
\hline & C. Biol. & 2,5 & 2,0 & 2,9 & 6,0 & 7,3 & 4,0 & 19,6 & 24,0 & 27,6 & 38,0 & 36,0 & 26,0 & 4,0 & 0,0 & 0,0 & 0,0 \\
\hline \multirow[t]{2}{*}{ Exatas } & E. Elét. & 1,9 & 3,4 & 1,5 & 0,0 & 5,5 & 10,3 & 14,9 & 27,6 & 30,5 & 34,5 & 43,1 & 24,1 & 2,2 & 0,0 & 0,5 & 0,0 \\
\hline & E. Cart. & 2,3 & 3,3 & 0,0 & 0,0 & 5,8 & 13,3 & 12,8 & 10,0 & 27,9 & 26,7 & 44,2 & 46,7 & 5,8 & 0,0 & 1,2 & 0,0 \\
\hline \multirow[t]{2}{*}{ Humanidades } & Let.-Tr. & 2,6 & 3,3 & 1,7 & 0,0 & 4,0 & 6,7 & 6,0 & 6,7 & 27,2 & 30,0 & 51,9 & 53,3 & 5,4 & 0,0 & 1,1 & 0,0 \\
\hline & C. Soc. & 13,8 & 16,7 & 6,5 & 6,7 & 5,7 & 8,3 & 14,6 & 8,3 & 18,7 & 25,0 & 39,0 & 33,3 & 1,6 & 1,7 & 0,0 & 0,0 \\
\hline
\end{tabular}


Tabela 5

Distribuição doscandidatosinsaritosematriculadossegundo ano detérmino do 2 Grau - Ano 1995

\begin{tabular}{|c|c|c|c|c|c|c|c|c|c|c|c|c|c|c|c|}
\hline \multirow[b]{2}{*}{ ÁREA } & \multirow[b]{2}{*}{ CURSO } & & \multicolumn{2}{|c|}{1.990 ou antes } & \multicolumn{2}{|c|}{1991} & \multicolumn{2}{|c|}{1992} & \multicolumn{2}{|c|}{1993} & \multicolumn{2}{|c|}{1994} & \multicolumn{2}{|c|}{1.995 ou após } & \multirow{2}{*}{$\begin{array}{c}\text { Sem } \\
\begin{array}{c}\% \\
\text { Inscritos }\end{array} \\
\end{array}$} \\
\hline & & & $\begin{array}{c}\% \\
\text { Inscritos } \\
\end{array}$ & $\%$ Matriculados & \begin{tabular}{|c|}
$\%$ \\
Inscritos \\
\end{tabular} & $\%$ Matriculado. & \begin{tabular}{|c|}
$\%$ \\
Inscritos \\
\end{tabular} & $\%$ Matriculado & $\begin{array}{c}\% \% \\
\text { Inscritios } \\
\end{array}$ & $\%$ Matriculado. & $\begin{array}{c}\% \\
\text { Inscrios } \\
\text { Intes }\end{array}$ & $\%$ Matriculados & $\begin{array}{c}\% \\
\text { Inscritos }\end{array}$ & $\%$ Matriculados: & \\
\hline \multirow[t]{2}{*}{ Biologicicas } & Medicina & Botucatu & 5,1 & 6,7 & 5,3 & 6,7 & \begin{tabular}{|l|}
12,9 \\
\end{tabular} & 20,0 & 27,5 & 41,1 & 43,9 & 24,4 & 4,8 & 0,0 & 0,5 \\
\hline & Biologia & Licenc. S. J. Rio Preto & 6,6 & 12,0 & 4,9 & 8,0 & 14,8 & 28,0 & 23,0 & 20,0 & 43,4 & 32,0 & 7,4 & 0,0 & 0,0 \\
\hline \multirow[t]{4}{*}{ Exatas } & Eng. Eletrica & Iha Solteira & 2,1 & 5,0 & 2,5 & 2,5 & 7,8 & 10,0 & 24,7 & 35,0 & 57,9 & 47,5 & 4,7 & 0,0 & 0,4 \\
\hline & Eng. Elétrica & Bauru & 3,6 & 3,3 & 2,7 & 0,0 & 11,1 & 20,0 & 29,3 & 40,0 & 50,3 & 36,7 & 2,6 & 0,0 & 0,4 \\
\hline & Eng. Elétrica & Guaratinguetá & 3,6 & 0,0 & 3,2 & 5,0 & 14,8 & 22,5 & 34,2 & 45,0 & 41,9 & 27,5 & 2,0 & 0,0 & 0,4 \\
\hline & Eng. Cartográfica & Pres. Prudente & 6,7 & 6,7 & 8,4 & 6,7 & 11,8 & 13,3 & 21,8 & 10,0 & 48,7 & 60,0 & 2,5 & 3,3 & 0,0 \\
\hline \multirow[t]{6}{*}{ Humanas } & Tradutores & Bacharelado & 4,0 & 6,3 & 3,1 & 0,0 & 8,6 & 9,4 & 23,3 & 31,3 & 54,2 & 53,1 & 6,4 & 0,0 & 0,4 \\
\hline & Direito & Matutino & 2,5 & 0,0 & 2,1 & 2,0 & 5,9 & 15,7 & 24,0 & 39,2 & 58,7 & 43,1 & 6,5 & 0,0 & 0,2 \\
\hline & Direito & Noturno & 9,2 & 13,7 & 4,2 & 5,9 & 9,6 & 13,7 & 23,9 & 27,5 & 48,6 & 37,3 & 3,4 & 0,0 & 1,1 \\
\hline & Arquitetura e Urbanismo & & 3,6 & 4,4 & 2,9 & 6,7 & 8,4 & 6,7 & 27,0 & 37,8 & 54,1 & 44,4 & 3,8 & 0,0 & 0,3 \\
\hline & Ciências Sociais & Matutino & 4,9 & 9,7 & 7,8 & 3,2 & 10,7 & 12,9 & 22,3 & 22,6 & 50,5 & 51,6 & 2,9 & 0,0 & 1,0 \\
\hline & Ciências Sociais & Noturno & 15,6 & 12,5 & 7,0 & 10,0 & 9,4 & 5,0 & 25,8 & 27,5 & 38,3 & 42,5 & 2,3 & 2,5 & 1,6 \\
\hline
\end{tabular}


Tabda 6

Distribuição doscandidatosinscritosematriculadossegundo

ano detérmino do $2^{\circ}$ Grau - Ano 1996

\begin{tabular}{|c|c|c|c|c|c|c|c|c|c|c|c|c|c|c|c|}
\hline \multirow[b]{2}{*}{ ÁREA } & \multirow[b]{2}{*}{ CURSO } & & \multicolumn{2}{|c|}{1.991 ou antes } & \multicolumn{2}{|c|}{1992} & \multicolumn{2}{|c|}{1993} & \multicolumn{2}{|c|}{1994} & \multicolumn{2}{|c|}{1995} & \multicolumn{2}{|c|}{1.996 ou após } & \multirow{2}{*}{\begin{tabular}{|c|}
$\mathrm{Sem}$ \\
$\%$ Inscritos \\
\end{tabular}} \\
\hline & & & \% Inscritos & re Mariciculados & $\%$ inscritos & $\%$ Marticulador & $\%$ Inscritos & $\%$ Matriculados & $\%$ Inscritos & $\%$ Marticulados & $\%$ Inscritos & $\%$ Matriculados & $\%$ Inscritos & $\%$ Matriculados & \\
\hline \multirow{2}{*}{ Biológicas } & Medicina & Botucatu & 5,8 & 4,4 & 5,4 & 7,8 & 12,6 & 21,1 & 27,2 & 47,8 & 43,6 & 18,9 & 4,5 & 0,0 & 0,9 \\
\hline & Biologia & Licenc. S. J. Rio Preto & 6,6 & 24,0 & 4,5 & 0,0 & 9,1 & 8,0 & 19,0 & 20,0 & 52,5 & 48,0 & 6,6 & 0,0 & 1,7 \\
\hline \multirow[t]{4}{*}{ Exatas } & Eng. Elétrica & Ilha Solteira & 4,1 & 2,5 & 4,9 & 7,5 & 9,6 & 12,5 & 25,3 & 35,0 & 50,9 & 42,5 & 4,7 & 0,0 & 0,5 \\
\hline & Eng. Eletrica & Bauru & 2,5 & 3,4 & 3,4 & 10,2 & 8,7 & 10,2 & 29,6 & 39,0 & 52,8 & 37,3 & 2,0 & 0,0 & 1,0 \\
\hline & Eng. Elétrica & Guaratinguetá & 4,0 & 2,9 & 3,1 & 5,7 & 10,6 & 20,0 & 33,7 & 31,4 & 46,2 & 40,0 & 1,9 & 0,0 & 0,5 \\
\hline & Eng. Cartográfica & Pres. Prudente & 2,7 & 7,5 & 3,6 & 2,5 & 12,5 & 7,5 & 33,0 & 45,0 & 43,8 & 37,5 & 4,5 & 0,0 & 0,0 \\
\hline \multirow[t]{6}{*}{ Humanas } & Tradutores & Bacharelado & 4,8 & 3,1 & 5,8 & 18,8 & 8,3 & 12,5 & 23,4 & 12,5 & 54,0 & 53,1 & 3,0 & 0,0 & 0,8 \\
\hline & Direito & Matutino & 2,4 & 2,0 & 2,4 & 2,0 & 5,3 & 12,0 & 23,3 & 34,0 & 59,6 & 50,0 & 6,2 & 0,0 & 0,9 \\
\hline & Direito & Noturno & 8,5 & 12,0 & 4,2 & 2,0 & 8,0 & 18,0 & 25,5 & 38,0 & 49,7 & 30,0 & 2,9 & 0,0 & 1,2 \\
\hline & Arquitetura e Urbanismo & & 4,1 & 2,2 & 3,0 & 4,4 & 7,6 & 13,3 & 28,3 & 35,6 & 52,9 & 42,2 & 3,5 & 0,0 & 0,6 \\
\hline & Ciências Sociais & Matutino & 5,4 & 6,3 & 8,7 & 3,1 & 12,0 & 21,9 & 22,8 & 34,4 & 45,7 & 34,4 & 5,4 & 0,0 & 0,0 \\
\hline & Ciências Sociais & Noturno & 13,8 & 20,0 & 11,7 & 4,4 & 5,5 & 2,2 & 23,4 & 26,7 & 42,1 & 42,2 & 2,1 & 4,4 & 1,4 \\
\hline
\end{tabular}


Em 1985/86, o "efeito cursinho" podia ser relacionado às possíveis deficiências da escola pública. Ainda bem que naquele momento não se tirou tal conclusão. É mais correto, portanto, pensar o cursinho como o local em que se aprende a fazer 0 vestibular. 0 nde ficou a tão decantada eficiência da escola particular?

Ciências Biológicas, apesar de ser o curso de menor prestígio da área, também exibia em 1985 esse deslocamento. A maioria dos inscritos se situava na categoria conclusão do 20 grau em 1984 (ver Tabela 4) e a maioria dos matriculados, na categoria conclusão do 2o grau em 1983. O bservem na tabela que o comportamento dos dados é semelhante ao dos de M edicina, com algumas nuanças já interpretadas naquele momento (W hitaker, 1989).

Em 1986, o fenômeno não se repetia da mesma forma para o curso aqui considerado. Curiosamente, parece não ter havido "efeito cursinho", já que $42,7 \%$ dos inscritos recém-formados compuseram $46 \%$ dos matriculados. Os concluintes em 1984 caíam ligeiramente (de $25,6 \%$ para $22 \%$ ) e o maior crescimento se dava para os formados em 1983, que passam de $12,4 \%$ para 22\%. Os de 1982 também cresciam ligeiramente. 0 "efeito cursinho" poderia ser vislumbrado apenas para os candidatos de 1983, o que é natural num curso de menor prestígio.

Por esse motivo, resolvemos comparar, em 1995, o curso de Biologia com o curso de Medicina, no que se refere a essa variável. O bservamos, então, que a distribuição dos candidatos inscritos para Biologia é, nesse caso, semelhante à dos de $M$ edicina. 0 s resultados, no entanto, são completamente diferentes na matrícula. Façamos um pequeno quadro comparativo entre esses dois cursos.

Q uadro B

Porcentagens de inscritosematriculados nos cursos deM edicina eC iências Biológicas, no Vestibular U nesp 1995, conformeano de conclusão do segundo grau.

\begin{tabular}{rccccc}
\hline & 1994 & 1993 & 1992 & 1991 & 1990 ou antes \\
\hline Medicina (inscr.) & 43,9 & 27,5 & 12,9 & 5,3 & 5,1 \\
(matr.) & 24,4 & 41,1 & 20,0 & 6,7 & 6,7 \\
C. Biológ. (inscr.) & 43,4 & 23,0 & 14,8 & 4,9 & 6,6 \\
(matr.) & 32,0 & 20,0 & 28,0 & 8,0 & 12,0 \\
\hline
\end{tabular}


Enquanto os candidatos a M edicina esbarram no seu primeiro vestibular, os de Ciências Biológicas também caem, mas não tão espetacularmente. Enquanto para M edicina todas as outras categorias sobem, os efeitos para Biologia apresentam mais nuanças. Os candidatos da categoria 1993 ainda caem na transição e as outras categorias sobem mais expressivamente do que as mesmas da M edicina. Em 1985, os efeitos eram mais mecanicamente observáveis. C resciam as duas categorias mais próximas e caíam as mais distantes. Diagnóstico de então: "efeito cursinho" para um e/ou dois anos anteriores ao vestibular e perda da capacidade de sucesso para os que sofreram sucessivas derrotas. O u seja: com um ou dois anos de cursinho, a aprovação ficava mais fácil. $M$ as, para aqueles que ainda assim fracassassem, 0 acesso ficava ainda mais difícil.

Parece, no entanto, que o fenômeno acima acontece com maior probabilidade na busca pelo curso de M edicina, já que, em 1996, para Biologia deu-se um imprevisível "efeito maturidade". 0 que estamos chamando de "efeito maturidade" reside exatamente no fato de que 0 maior sucesso percentual no vestibular se deu justamente na categoria daqueles que terminaram o colegial em 1991 ou antes, ou seja, 5 anos ou mais antes do concurso (e com variações meio aleatórias nas outras categorias). Realmente, com apenas 6,6\% de participação na inscrição, eles serão $24 \%$ dos matriculados - uma subida espetacular, muito difícil de explicar (Tabela 5). É possível pensar aqui em ex-candidatos a M edicina, desiludidos por sucessivas derrotas e que se apresentaram tranqüilos ao vestibular de Biologia. $M$ as é preciso cuidado numa interpretação desse tipo. A análise científica em alguns momentos levanta mais questões do que resolve. É necessário observar, voltando ao Quadro B, que tanto para M edicina, como principalmente para Biologia, o "efeito maturidade" já se anunciava. N a realidade, os inscritos nos anos de 1992 para trás, em vários momentos, dobram sua participação na matrícula.

Já para os dados de 1985/86, a porcentagem dos recém-formados prestando vestibular em raros casos ultrapassava os $45 \%$. É um indicador do óbvio. A maioria dos jovens que aspiram à universidade pública, principalmente em relação aos cursos de mais prestígio, tem um compasso de espera que implica prestar vestibular durante dois ou três anos sucessivos.

Assim é que, em 1985, 43,1\% dos candidatos inscritos para Engenharia Elétrica de Ilha Solteira eram recém-saídos do ensino médio. $M$ aioria, mas não absoluta, com os restantes distribuindo-se pelos anos anteriores de conclusão do $2^{\circ}$ grau.

0 curso é de prestígio? Q ueda para 24,1\% de matriculados para tal jovem categoria. Enquanto isso, cresciam todas as outras categorias, 
algumas duplicando sua porcentagem, com exceção apenas da "classe de 1980", que desapareceu na transição.

Para desapontamento nosso, em 1986 os dados se comportaram de forma um pouco diferente. $0 \mathrm{~s}$ recém-formados tiveram relativo sucesso no vestibular, subindo de $46,8 \%$ para $48,3 \%$, enquanto a "classe de 1984" perdeu pontos na transição. Aquilo que estamos tratando de "efeito cursinho" apareceu com grande nitidez para os formados em 1983, que subiram 10 pontos percentuais. $\mathrm{N}$ ão deixou de acontecer, mas ocorreu de forma deslocada e concentrada.

D ecorridos 10 anos, o que mudou? Em 1995, é maior a porcentagem de candidatos recém-saídos do ensino médio: 57,9\%, a segunda maior no conjunto, com as restantes categorias em porcentagens decrescentes (Tabela 5).

"Efeito cursinho" ou que outro nome se queira atribuir, o fenômeno se dá em 1995 de forma bastante mecânica, bem ao gosto do quantitativismo, para o curso de Engenharia Elétrica de Ilha Solteira.

Assim, aqueles $57,9 \%$ de candidatos com término do ensino médio imediatamente anterior caem para $47,5 \%$ dos matriculados, enquanto sobem (ou se mantêm - caso dos candidatos de 1991) todas as outras categorias. $M$ as se pode perceber nuanças, levando em conta a localização do campus de Ilha Solteira. Será que todos os aprovados logo em 1994 são vestibulandos apenas da U nesp?

Parece que Engenharia Elétrica de Bauru repete I lha Solteira no modelo de procura, com variações nas porcentagens (variações significativas nas categorias 1993 e 1990 ou antes). M as a aprovação terá modelo diferente. O bservem o Q uadro $\mathrm{C}$, comparativo.

\section{Q uadro C}

Porcentagens de Inscritose $M$ atriculadosno Curso de Engenharia Elétrica deBauru, no Vestibular U nesp 1995, conforme ano de conclusão do ensino médio (D emonstrativo do "efeito cursinho")

\begin{tabular}{ccc}
\hline Ano de conclusão & \% de inscritos & \% de matriculados \\
\hline 1994 & 50,3 & 36,7 \\
1993 & 29,3 & 40,0 \\
1992 & 11,1 & 20,0 \\
1991 & 2,7 & 0,0 \\
1990 ou antes & 3,6 & 3,3 \\
\hline
\end{tabular}


Sucesso maior para os de um ou dois anos de espera e fracasso para os mais distantes, tal como o padrão da M edicina (maior elitização do curso? região mais rica?).

Em Engenharia Elétrica de Guaratinguetá temos diferenças no perfil da procura. $\mathrm{N}$ ão é maioria absoluta que busca o vestibular logo após o término do colegial. É maioria expressiva $(41,9 \%)$, mas não é absoluta. $\mathrm{N}$ a categoria conclusão em 93 há maior concentração do que nas outras duas Engenharias Elétricas: são 34,2\%. E também nas outras categorias expectantes, as porcentagens são maiores do que em Bauru e Ilha Solteira. M as a queda dos mais jovens é tão ou mais expressiva do que nas outras duas faculdades.

Comparemos. Em Il ha Solteira, a categoria 1994 perdeu mais ou menos 10 pontos percentuais na transição inscritos/matriculados. Em Bauru, perdeu mais ou menos 14 pontos. Em Guaratinguetá, a queda repete Bauru (14,4 pontos), sendo, portanto, um pouco mais expressiva do que em Ilha Solteira. E, com exceção dos vestibulandos que terminaram o ensino médio em 1991, todas as outras categorias sobem (maior semelhança com Ilha Solteira do que com Bauru).

O s dados do término do 20 grau para Engenharia Elétrica de Bauru, em 1996, repetem os de 1995, com grande similaridade, nas duas categorias imediatamente anteriores ao ano do vestibular (Tabela 6). Mas, de repente, na classe de 1993 dá-se um certo desvanecimento do "efeito cursinho", despontando-se o "efeito maturidade". Crescem, na direção das matrículas, todas as categorias, de 1993 para trás, mesmo quando a procura tenha sido menor do que no ano anterior.

Já Engenharia Elétrica de Guaratinguetá apresenta menos nuanças do "efeito cursinho" em relação ao ano anterior. Contudo, ele bloqueia agora, com maior eficiência, a chegada à U niversidade daqueles que ainda não têm dois anos de espera. O bservem, nas tabelas correspondentes, que aqueles que teoricamente fizeram um ano de cursinho ainda eram 45\% dos matriculados em 1995, mas serão apenas 31,4\% em 1996 isto no curso que verificamos ser o menos elitizado dentre as Engenharias Elétricas da Unesp.

Vejamos agora o curso de menor procura. Q uanto menor a procura, obviamente maior a probabilidade de sucesso no vestibular, logo à saída do $2^{\circ}$ grau.

Assim, para Engenharia C artográfica, 48,7\% dos inscritos acabaram de sair do $2^{\circ}$ grau e serão $60 \%$ dos matriculados. Embora a distri- 
buição dos inscritos reproduza a das Engenharias Elétricas, com variações evidentemente nos percentuais, na hora da matrícula o fenômeno é inverso. Sobe a porcentagem da categoria conclusão em 1994, enquanto, à exceção da categoria conclusão em 1992, todas as outras caem ou se mantêm, como é o caso de 1991 ou antes (Tabela 5).

0 resultado nos faz pensar em alunos menos maduros nessa Engenharia e, talvez, mais criativos, dada a menor domesticação. Tal como há 10 anos, o sucesso aqui é maior para o recém formado. E tal como há 10 anos, devemos perguntar o que há por detrás dos números.

$\mathrm{N}$ aquele momento, havia uma categoria de exceção: os que terminaram em 1981 (hoje são os de 1992). Vale a pena recordar 1985, antes de enfrentar os dados de 1996. O bservem na Tabela 4 que o perfil de distribuição das porcentagens dos inscritos se repete para os matriculados, apesar das duas nuanças: sucesso relativo dos recém-formados (crescimento de 2,5 pontos percentuais na transição inscritos/matriculados); e sucesso inesperado da "classe 1981" (5,8\% de inscritos para 13,3\% de matriculados), resultado de pouco significado dado o pequeno número de candidatos envolvidos. 0 "efeito cursinho" parecia não ocorrer para este curso de menor prestígio das Exatas, o que se confirmava para 1986 e voltou a acontecer em 1995.

Em 1996, no entanto, o referido efeito se insinuou novamente. Vejam na Tabela 6 como os recém-formados de 1995 caem de 43,8\% para 37,5\%, enquanto a "classe 1994" cresce de 33\% para 45,0\%, numa quase inversão dos dados. No entanto, para os candidatos formados em 1993 e 1992 houve perdas, enquanto os "mais velhos" ganham na transição, passando de 2,7\% para 7,5\% dos ingressantes.

Este sucesso inesperado dos alunos em maior compasso de espera, embora com pequeno significado por causa da pouca magnitude dos números absolutos, merece atenção, já que se repete nos quatro anos analisados. Seriam candidatos superpreparados que desistiram de outras Engenharias? Seriam graduados de outros cursos de Exatas, buscando novos caminhos? As possibilidades infinitas das relações, quando analisadas sociologicamente, são sedutoras. $M$ as devemos voltar àquelas mais concretamente detectávess, como o fenômeno ao qual chamamos "efeito cursinho".

Em 1985/86, esse efeito ia diminuindo, à medida que se passava das Exatas para as $\mathrm{H}$ umanidades. Resumindo, pode-se afirmar que, para o curso de Letras-Tradutor, os formados em 1983 e 1984 eram quase $80 \%$ dos inscritos e cresciam percentualmente na transição (ver dados 
na Tabela 4). O s dados de 1986 confirmariam esta análise de forma ainda mais clara, já que, naquele momento, cresceu para $56,1 \%$ a porcentagem dos recém-formados que conquistaram $63,3 \%$ das vagas no momento da matrícula.

0 resultado acima era intrigante num curso de prestígio. Podia-se pensar que um bom preparo em língua estrangeira, desde a infância, teria ajudado a definir esta escolha. $E$, sendo assim, não havia tanta necessidade das artimanhas do cursinho para obter sucesso no vestibular.

Acontece que, em 10 anos, o quadro se alterou. O bservem na Tabela 5 como recém-formados já perdem pontos na transição inscritos/ matriculados. A perda é insignificante ( 1,1 pontos percentuais), mas aqueles que esperavam entrar desde 1993 saltam de 23,3\% para 31,3\%. Há ganhos também para a "classe 1992", e até os candidatos de 1990 sobem. À custa de quem todos esses ganhos, se as perdas são tão pequenas para os recém-formados? D uas classes desaparecem: a de 1991 e a dos "treineiros", que eram 6,4\%.

Para 1996, os dados se apresentam estranhos. N um primeiro momento, quase diríamos que o "efeito cursinho" não se faz sentir. Afinal, 54\% dos candidatos recém-formados serão 53,1\% dos matriculados. Além da queda ser insignificante, os candidatos do ano anterior caem espetacularmente (de $23,4 \%$ para $12,5 \%$ ). 0 que perturba a análise é o fato de que os candidatos que terminaram o colegial em 1993 e 1992 alcançam maior sucesso, especialmente os de 1992. O bservem na Tabela 6 que, se somarmos os dados dessas duas categorias, teremos $14,1 \%$ dos inscritos crescendo para $31,3 \%$ dos matriculados (1/3 dos vitoriosos).

Aqui podemos apenas especular. A globalização dos mercados estaria tornando mais acirrada a concorrência para este curso, atraindo ou exigindo maior preparo para aprovação? Candidatos mais maduros estariam migrando de outras áreas para esta carreira promissora? Q uestões, questões, questões...

De qualquer forma, os dados mostram a falácia das generalizações apressadas. Costuma-se pensar sempre em menores índices de prestígio para áreas ligadas a humanidades, quando basta tomar cursos de maior procura dentro dessa área e encontrar os dados demonstrando que o prestígio de um curso não é questão de área, e sim de carreira.

Veremos agora como o curso de Direito acompanha o padrão das Biológicas no que se refere a esta variável. Assim é que os recém-formados sofrem derrota no concurso vestibular de 1995 , tendo caído de $58,7 \%$ e 
$48,6 \%$ (inscritos para o matutino e o noturno, respectivamente) para $43,1 \%$ e $37,3 \%$, sendo maior a queda para os candidatos ao diurno. Sintomaticamente, os "treineiros" desaparecem. A "classe 1993" sobe na transição. Interessante notar que os inscritos para o diurno sobem proporcionalmente ao que caíram os recém-formados ( 15,2 pontos percentuais). Para não sobrecarregar o texto, basta observar que 0 crescimento dos percentuais na transição inscritos/matriculados se dá para todas as outras categorias em D ireito noturno, e no matutino sofre exceção apenas para os "mais velhos", que desaparecem.

O s dados de 1996 repetem o fenômeno aqui considerado. Só que agora a queda é maior para os recém-formados que se inscreveram para o noturno, que caem quase 20 pontos percentuais no momento da matrícula. Ganham quase todas as outras categorias, com exceção da "classe 1992". O s candidatos "mais velhos" (1991 ou antes) vão subir de 8,5\% para $12 \%$, o que nos faz pensar em contabilistas ou já graduados em Economia tentando novos caminhos.

Trabalhadores-estudantes em cursos de prestígio? U m bom tema para pesquisa. Já para o diurno, os maiores ganhos estão nas categorias mais jovens (um ou dois anos de cursinho?), num padrão semelhante ao dos candidatos a M edicina. Se somarmos as porcentagens dessas duas categorias, teremos $28,6 \%$ dos inscritos que passaram um ou dois anos em compasso de espera e serão 36\% dos matriculados.

0 "efeito cursinho" nas H umanidades, observável em Direito, vai ser confirmado pelo movimento dos candidatos de Arquitetura e Urbanismo em 1995. O s recém-formados perdem 10 pontos percentuais na transição inscritos/matriculados, e esses 10 pontos serão aproveitados de forma imediata pela categoria conclusão em 1993 (54,1\% caindo para $44,4 \%$ para os inscritos de 1994 e $27 \%$ subindo para $37,8 \%$ para os inscritos de 1993). N o mais, sobem as categorias com término mais distante do momento do vestibular e caem apenas os da "classe 1992". Com ligeiras variações, o fenômeno se repete para 1996, com queda das porcentagens na transição inscritos/matriculados para as duas categorias extremas, e crescimento da participação no momento da matrícula para as categorias intermediárias.

O compasso de espera nos cursos de prestígio independe, portanto, da área. É função da carreira e não de um hipotético desprestígio das Ciências H umanas. Afinal, em 1996, com um ano a mais de estudo, os 28,3\% de inscritos formados no colegial em 1994 fazem crescer sua participação para 35,6\% no momento da matrícula. Se somarmos a parti- 
cipação das categorias intermediárias na composição dos matriculados, veremos que mais de $55 \%$ dos que compõem esta classe de Arquitetura não são jovens que acabaram de sair do colegial. Estiveram, portanto, preparando-se de uma forma ou de outra para chegar a esta seleção.

É claro que, em Ciências Sociais, os dados se comportam de forma diferente. Já em 1985 observava-se que não se fazia sentir, neste curso, 0 compasso de espera que caracteriza o "efeito cursinho". O bservando a Tabela 4, pode-se até pensar em algo semelhante, mas com intensidade bem menor. Assim é que os inscritos recém-formados perdiam mais de 5 pontos percentuais na transição para matrícula, com ganhos para a segunda categoria considerada ("classe 1983"). H avia perdas equivalentes, no entanto, para os formados em 1982 e ganhos para os de 1981, o que embaral hava um pouco os resultados. 0 que chamava atenção nessa época era a mais alta porcentagem de candidatos maduros (13,8\% de inscritos que haviam terminado o colegial em 1979 ou antes, e que se tornaram $16,7 \%$ dos matriculados). Essa maturidade se confirma quando somamos as porcentagens dos recém-formados com as da "classe 1983", tanto para inscritos como para matriculados, e vamos encontrar aí as concentrações mais baixas do conjunto. São $47,6 \%$ de inscritos contra quase $80 \%$, no caso de Letras-Tradutores. $E$, no momento da matrícula, são apenas $58,3 \%$ contra $83,3 \%$, no caso de Letras-Tradutores. $0 \mathrm{~s}$ dados de 1986 confirmariam, com pequenas variações, o observado em 1985, quanto à "maturidade" dos inscritos e matriculados.

0 que mudou em 10 anos? $0 \mathrm{~s}$ dados, agora desagregados para matutino e noturno, são mais reveladores. Sabemos que, para todos os cursos, cresceram nestes 10 anos as porcentagens de inscritos recémformados (embora nem sempre as de matriculados). Pois bem, Ciências Sociais apresenta para o matutino $50,5 \%$ de inscritos nessa categoria, porcentagem equivalente à de Engenharia Elétrica de Bauru. Porém, os inscritos recém-formados para o curso noturno estão em porcentagem ainda menor do que em 1985. É a única porcentagem abaixo de $40 \%$ no conjunto de todos os cursos.

0 que acontece com essas porcentagens na transição para matriculados? Contrariamente à maioria dos casos, essas porcentagens sobem na transição, embora não tanto como em Engenharia Cartográfica. As porcentagens dos que terminaram o colegial em 1993 se mantêm com ligeira subida para os inscritos no noturno. A "classe 1992" ganha no matutino e perde no noturno. O s candidatos "mais velhos" ganham participação de maneira "cruzada": os de 1991 ganham no noturno e perdem no diurno, enquanto os de 1990 ou antes ganham no matutino 
e perdem no noturno. M as, ainda assim, é no curso noturno de Ciências Sociais que se concentra a maior porcentagem de matriculados "mais velhos". São $22,5 \%$, se somarmos as porcentagens das duas categorias com o término do colegial mais distante do momento do vestibular (Tabela 5).

Q uanto a 1996, observa-se que o "efeito cursinho" se faz sentir para o matutino, o que não acontecia em 1995. Eles são 45,7\% dos inscritos na categoria conclusão do 20 grau em 1995 e caem para 34,4\% dos matriculados, com ganhos nas categorias intermediárias, que é justamente onde se define o "efeito cursinho" (Tabela 6).

Já no curso noturno, acentua-se o "efeito maturidade" e continua a ausência do "efeito cursinho". Aliás, o "efeito maturidade" apresenta crescimento significativo em 1996. A categoria dos "mais velhos", que era de $12,5 \%$ dos matriculados em 1995 , agora é de $13,8 \%$ já no momento da inscrição, e cresce espetacularmente para $20 \%$ no momento da matrícula. O s dados do curso de Ciências Sociais noturno assemelhamse mais aos dados agregados de 1985 (comparem as tabelas), enquanto 0 matutino se elitiza relativamente.

Conforme anunciado no início deste artigo, escolhemos duas variáveis expressivas da nossa pesquisa que ajudam a compreender as complexas relações entre 0 ensino médio e 0 acesso à U niversidade. Especialmente a questão do "efeito cursinho" parece-nos crucial porque ajuda a pensar as falácias sobre qualidade de ensino. É preciso esclarecer aqui que nossa pesquisa aprofunda a questão do "efeito cursinho" com a análise de uma outra variável: freqüência ou não a cursinho associada à duração dessa freqüência. O s dados desta variável confirmam as relações aqui estabelecidas. Realmente, o compasso de espera dos candidatos reflete um tempo passado dentro das salas de aula dessa notável invenção tupiniquim, que paradoxal mente abre as portas da U niversidade a grande porcentagem de candidatos.

Cumpre, neste momento, lembrar alguns aspectos sistêmicos que ajudam a relativizar resultados que apontam para a eficiência da escola particular versus da escola pública do ensino médio.

1) 0 "efeito cursinho" mostra que a escola particular continua não garantindo o sucesso no vestibular, tal como já acontecia nos anos 80.

2) 0 fato de o perfil do candidato U nesp não trazer mais a marca da escola pública, o que ocorre para os cursos de prestígio, não 
implica necessariamente elitização da clientela e tem a ver muito mais com mudanças no comportamento da classe média, que se vê pressionada pela "modernidade" a consumir símbolos de status, tais como computadores, celulares, forno de microondas e obviamente "marcas" da escola particular.

3) Tal como no caso do ensino fundamental, a escola particular do ensino médio pode estar sendo abandonada pela classe média, pressionada agora muito mais pelas agruras do Plano Real, que entram em contradição com as exigências do consumo.

Cumpre lembrar aqui avaliações oficiais que, no caso do estado de São Paulo, por exemplo, puseram em relevo escolas públicas com desempenho equivalente ao das particulares.

Atualmente, a todo começo de ano, formam-se filas às portas de escolas públicas reconhecidamente eficientes, notadamente aquelas mantidas por prefeituras progressistas que pagam melhor seus professores, e nas quais famílias podem chegar até a passar a noite. ${ }^{8}$

São quadros do cotidiano que podem estar anunciando mudanças substanciais para esta variável em futuro próximo. Importante assinalar aqui que trabalhamos com diferentes perfis de vestibulandos e, nesse sentido, a mudança acima discutida não se fez de forma inexorável. M uito ao contrário, a escola pública de ensino médio continua marca forte em muitos cursos e, para alguns, tornou-se marca ainda mais forte do que no passado. É o caso de Engenharia Cartográfica, que apresentava, em 1985, 26,7\% dos matriculados com toda formação em escola particular de $2^{\circ}$ grau e hoje apresenta apenas $16,7 \%$, um claro processo de deselitização.

Dirão alguns que é curso de menor prestígio. Com certeza. $M$ as a Engenharia Elétrica de G uaratinguetá vai apresentar, tanto em 1995 como em 1996, uma performance melhor para os vestibulandos que vieram da escola pública de ensino médio. Estamos aqui diante de uma das singularidades desta pesquisa. Esta Engenharia Elétrica apresenta intrigantes resultados para um curso de prestígio.

O importante, agora, é aliar estas observações ao quadro geral dos outros cursos e verificar as altas porcentagens de candidatos com ensino médio total ou parcialmente cursado em escola pública, que até fazem sucesso ou sobrevivem em diferentes cursos da Unesp.

Assim, a Unesp não perdeu, em verdade, sua ligação com a escola pública de ensino médio. ${ }^{9} 0$ que está acontecendo é que vão deixando 
de passar por esse tipo de ensino os privilegiados, com destino marcado na direção dos cursos de prestígio. No entanto, há uma persistência do alunado da escola pública de ensino médio às portas da U niversidade pública. E eles até ganham algumas batalhas, o que nos desautoriza, conforme assinal ado durante a análise, de avaliar qualquer escola de ensino médio a partir destes "sucessos", e nos anima a pensar na recuperação da escola pública, como conseqüência das pressões sistêmicas dos estratos médios que a elas regressam.

Conforme foi assinalado para 1985/86, mais importante do que escola pública versus escola particular é o divisor diurno versus noturno no ensino médio, realizado pelos candidatos.

0 efeito do ensino médio já era esmagador, no sentido de bloquear o gargalo do vestibular à entrada da Universidade pública e não fez mais do que se acentuar para a área das Biológicas, na qual a grande competição pelas vagas de $M$ edicina acabou por quase eliminar as pequenas possibilidades que ainda existiam no passado.

$\mathrm{N}$ a área de Exatas, há um pouco mais de espaço para a entrada dos egressos do ensino médio noturno, com variações que atingem mesmo a mais elitizada Engenharia Elétrica (Bauru), cujos dados de 1996 se deselitizam levemente em relação a esta variável. E mais. A Engenharia Elétrica de Guaratinguetá vai acentuando seu papel de menos elitizada das três engenharias aqui consideradas, abrindo ainda mais espaço, em 1996, para os candidatos com passagem parcial ou total pelos cursos noturnos de ensino médio.

$\mathrm{N}$ as elitizadíssimas carreiras ligadas à área de H umanidades, não sobra evidentemente muito espaço para a categoria ensino médio noturno. M esmo o curso de D ireito noturno tem demanda bastante elitizada no que se refere a esta variável. São $55,1 \%$ de egressos do ensino médio diurno buscando este curso noturno, o que nos fez levantar duas hipóteses não excludentes para os filhos de uma classe média em processo de pauperização: a maior esperança de classificação e/ou necessidade de trabalhar.

$M$ as como expressava a pesquisa dos anos 80 , "até entram trabalhadores na Unesp", já que, afinal, o que é um estudante de ensino médio noturno senão um trabalhador que estuda? $\mathrm{N}$ aquele momento, eles entravam preferencialmente em Engenharia Cartográfica e Ciências Sociais, além de Engenharia Elétrica de Ilha Solteira.

$\mathrm{H}$ oje, o fenômeno permanece para Engenharia C artográfica, mas sofre perturbação intrigante para Ciências Sociais, no que se refere ao vestibular de 1995. Foi nesse momento que começou a se delinear entre 
os dados o que estamos chamando "efeito Fernando H enrique", uma certa elitização dos candidatos a Ciências Sociais em 1995, que se desvanece em 1996.

A mais importante descoberta desta pesquisa, no entanto, relaciona-se a fatores complexos ligados ao preparo para o vestibular. 0 bservou-se, a partir destes dados, que, embora fugindo da escola pública, supostamente inoperante, e realizando o ensino médio (e mesmo o ensino fundamental) na particular, os privilegiados necessitam mais do que nunca daquilo que há 10 anos batizou-se de "efeito cursinho". Esta necessidade tornou-se evidente, uma vez que altas porcentagens de candidatos apresentam-se agora "sem cursinho", o que não acontecia nos anos 80. Estas altas porcentagens sugerem que a confiança no preparo dado pela escola particular (ou por outras formas de preparo) é muito grande por parte da maioria dos candidatos. ${ }^{10} \mathrm{~N}$ o entanto, a categoria dos semcursinho sofre quedas vertiginosas na transição inscritos-matriculados, demonstrando que pagar mensalidades caríssimas durante os anos que antecedem 0 vestibular pode ser útil a muitos propósitos dos pais, quando investem na educação dos filhos, mas não elimina os gastos com um, dois, até três anos de cursinho.

A divulgação destes dados é necessária para alertar as famílias sobre um produto que está sendo comprado por elas e que nem sempre está sendo adquirido. 0 passaporte para a Universidade exige ainda outros pré-requisitos. ${ }^{11}$

Assim, embora não possamos usar tão tranqüilamente a expressão "efeito cursinho" - uma vez que outras formas de preparo para o vestibular estão em alta para os mais abastados, o que pode aconselhar a expressão "efeito retardo" - , o que nossos dados de 1995/96 revelam é que o "efeito cursinho" permanece e se expressa com mais evidência, apesar, ou até mesmo porque muitos deixaram de acreditar nele.

Recebido para publicação em julho de 2000.

N otas

1. Conforme se verá adiante, eram sempre altas as porcentagens de candidatos da escola pública naquele momento e na transição inscritos/matriculados essas porcentagens subiam, uma prova clara do sucesso do aluno da escola pública

2. Os dados de 1986 confirmariam este quadro, com duas tendências contraditórias: por um lado crescia um pouco a porcentagem de inscritos com "toda escola particular de 20 grau" $(50,5 \%)$ e por outro lado os candidatos da escola pública de 20 grau faziam maior sucesso do que no ano anterior. Eram 32,7\% dos inscritos e subiam para 35,6\% dos matriculados. 
3. A política anti-social do governo neoliberal está revertendo o processo. Aguardemos as conseqüências.

4. Até porque queremos evitar um texto cansativo que padroniza as análises sem a dialética da crítica.

5. Em 1986, os dados são os seguintes: $44,2 \%$ vinham da escola pública e caíam para $34 \%$ dos matriculados, enquanto $37,6 \%$ da particular subiam para $51,1 \%$.

6. 0 paradoxo é evidente e está na performance da categoria 20 grau maior parte na escola pública.

7. É fenômeno conhecido e divulgado pela mídia o fato de que na desorientação do momento muitos vestibulandos prestam vários e diferentes concursos na ânsia de conseguir a sonhada aprovação. Assim é comum, por exemplo, que um jovem se inscreva para um vestibular de curso altamente profissionalizante e ao mesmo tempo para vários cursos de baixa procura em diferentes áreas.

8. Ver por exemplo, Gaspari, E. As filas de Campinas foram uma aula, Folha de S. Paulo, 5 de janeiro de 1997.

9. D ados gerais organizados por M iranda dos Santos para 1993 mostram que, embora a maior parte dos candidatos Vunesp daquele ano viesse da escola particular de 20 grau $(54 \%$ × $45 \%$ da pública), no momento da matrícula, o quadro se alterou (50\% da pública x $49 \%$ da particular).

10. Em 1985, os inscritos para M edicina na categoria dos sem cursinho eram de apenas $25,6 \%$. H oje são $35,5 \%$. Para Engenharia Elétrica de Ilha Solteira eram $36,0 \%$. H oje alcançam $56,7 \%$. M ais de $50 \%$ apresentam-se sem cursinho para cursos de demanda elitizada como D ireito, o que corrobora nossa tese sobre uma confiança na Escola Particular de $2^{\circ}$ grau que não se concretiza.

11. Sabemos que os adolescentes não vão para a escola particular apenas em busca de um passaporte para a U niversidade. Trata-seá do encontro entre iguais, do credenciamento social, da socialização para o status que a família conquistou etc...

\section{Secondary School: A matter of State or enterprise?}

ABST RACT: The present paper discuss important subjects concerning the quality of the public high school when compared to the private, starting from data of the research "10 years later - UNESP - candidatés different profiles for different courses (Study of variables of Cultural Capital)", questioning the ideological vision that the privateschool places your students mechanically in the best U niversities. Presenting data on the performance of candidates to the vestibular examination originating from of the private system and of the public system, the article shows that in the two cases the frequency to preparatory courses is a constant, what places so in check the supposed best quality of the private high school.

Key words: Secondary School; State or Business Secondary School; Preparatory course effect; U niversity admittance. 
DEBATES 